\title{
Surveys of 12 California crops for phytoseiid predatory mites show changes compared to earlier studies
}

In phytoseiid samples from 25 counties from 2000 to 2018, the western predatory mite, long recognized as an important biological control agent, was found in relatively low numbers.

by Elizabeth E. Grafton-Cardwell, Walter Bentley, Mary Bianchi, Frances E. Cave, Rachel Elkins, Larry Godfrey, Ping Gu, David Haviland, David Headrick, Mark Hoddle, James McMurtry, Maria Murrietta, Nicholas Mills, Yuling Ouyang, Carolyn Pickel, Stephanie Rill, Menelaos C. Stavrinides and Lucia G. Varela

$\mathrm{P}$ redatory mites in the family Phytoseiidae are important predators of pest mites in agricultural crops, regulating to varying levels populations of pest spider mites (Tetranychidae), as well as small insects such as immature thrips (McMurtry and Croft 1997). There are more than 2,000 described species of phytoseiids, and probably many more are yet to be discovered. The extensive monograph of Schuster and Pritchard (1963) on the Phytoseiidae of California described 52 species, and about 16 additional species have been discovered or introduced since.

The food habits and lifestyles of phytoseiids vary considerably but can be categorized as follows: Type I phytoseiids are highly specialized predatory mites in the genus Phytoseiulus that feed almost exclusively on heavy-web-spinning tetranychid spider mites. Type II phytoseiids are specialized predatory mites

\section{Abstract}

Phytoseiid mites are key predators in agricultural crops. However, not all species regulate pest populations below economic thresholds, and therefore knowledge of which species are associated with particular crops aids pest control recommendations. Surveys of 12 crops across six geographical regions of California demonstrated that phytoseiid species varied by crop and geographical location, with subtropical crops exhibiting the lowest species diversity and grape the greatest. The western predatory mite, Galendromus occidentalis, long cited as a dominant species in California crops, was not found to be the major species in most situations. Euseius stipulatus, a species introduced in the 1970s, was found in the surveyed crops in many areas of the state and appears to be displacing E. hibisci along the south coast. 
represented by Galendromus species and some species of Neoseiulus; they tolerate webbing and prefer spider mites but also prey on other groups of mites such as eriophyids (rust or bud mites), tarsonemids and tydeiids, as well as feed on pollen. Type III phytoseiids in the genera Amblyseius, Typhlodromalus, Typhlodromus and Metaseiulus avoid the heavy webbing produced by Tetranychus species and instead feed on mites such as Panonychus species (red mites), eriophyids, tarsonemids and tydeiids and also on thrips, whiteflies and other small insects, and on pollen, fungi and plant exudates. Type IV phytoseiids in the genus Euseius are highly adapted to pollen and leaf sap feeding, often showing rapid population increases during leaf flush and flowering periods, but may help suppress non-web-spinning spider mites and thrips (McMurtry and Croft 1997; McMurtry et al. 2013).

Type I and II phytoseiids have adaptations to move through spider mite webbing and have demonstrated

TABLE 1. Species of phytoseiid predatory mites found in 12 permanent or semipermanent cropping systems in California

\begin{tabular}{|c|c|c|c|c|c|c|c|c|c|c|c|c|c|c|}
\hline Host plant & $\begin{array}{c}\text { Collection } \\
\text { years }\end{array}$ & Counties & $\begin{array}{c}\text { Site- } \\
\text { years* }\end{array}$ & $\begin{array}{l}\text { Seasonal } \\
\text { samplest }\end{array}$ & $\begin{array}{l}\text { No. of } \\
\text { mites }\end{array}$ & 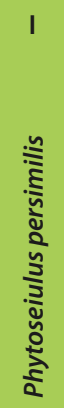 & 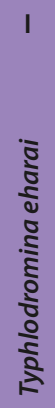 & 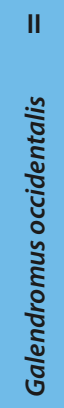 & 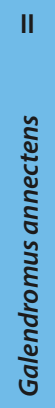 & 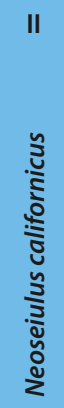 & 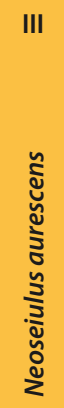 & 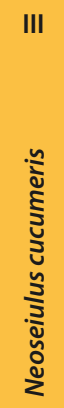 & 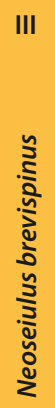 & 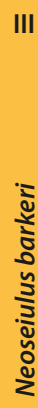 \\
\hline Citrus & $2006-2018$ & $\begin{array}{l}\text { Fresno, Tulare, Kern, } \\
\text { Santa Barbara, } \\
\text { Riverside, San } \\
\text { Bernardino }\end{array}$ & 21 & No & 994 & 0 & 0 & 0 & 0 & 0 & 0 & 0 & 0 & 0 \\
\hline Avocado & 2000-2007 & $\begin{array}{l}\text { San Luis Obispo, } \\
\text { Orange }\end{array}$ & 11 & Yes & 1,892 & 0 & 1 & 3 & 37 & 4 & 0 & 0 & 0 & 0 \\
\hline Cherimoya & 2006-2007 & $\begin{array}{l}\text { Santa Barbara, } \\
\text { Ventura }\end{array}$ & 3 & Yes & 104 & 0 & 0 & 2 & 0 & 0 & 0 & 0 & 0 & 0 \\
\hline Blackberry & 2006-2007 & San Luis Obispo & 2 & Yes & 106 & 0 & 9 & 14 & 24 & 49 & 0 & 0 & 0 & 0 \\
\hline Raspberry & 2006-2007 & $\begin{array}{l}\text { San Luis Obispo, } \\
\text { Ventura }\end{array}$ & 10 & Yes & 239 & 50 & 2 & 0 & 0 & 26 & 0 & 0 & 0 & 0 \\
\hline Strawberry & 2006-2010 & $\begin{array}{l}\text { Santa Cruz, Santa } \\
\text { Barbara, Ventura }\end{array}$ & 18 & Yes & 1,570 & 271 & 0 & 0 & 0 & 612 & 403 & 204 & 19 & 5 \\
\hline Grape & 2005-2010 & $\begin{array}{l}\text { Lake, Napa, } \\
\text { Mendocino, } \\
\text { Sonoma, Madera, } \\
\text { San Joaquin, Kern, } \\
\text { Ventura, San Luis } \\
\text { Obispo, Monterey }\end{array}$ & 78 & Yes & 5,604 & 13 & 5 & 415 & 0 & 87 & 12 & 1 & 0 & 1 \\
\hline Peach/ nectarine & 2006-2007 & $\begin{array}{l}\text { Butte, Fresno, Kings, } \\
\text { Tulare, Kern }\end{array}$ & 19 & No & 576 & 0 & 0 & 35 & 0 & 1 & 0 & 0 & 0 & 0 \\
\hline Plum/ prune & 2006-2007 & Butte, Kern & 4 & No & 67 & 0 & 0 & 3 & 0 & 0 & 0 & 0 & 0 & 0 \\
\hline Pear & 1996-2008 & $\begin{array}{l}\text { Lake, Mendocino, } \\
\text { Sacramento, Yolo }\end{array}$ & 30 & Yes & 800 & 0 & 0 & 71 & 0 & 4 & 0 & 0 & 0 & 0 \\
\hline Almond & $2006-2018$ & Kern, Butte & 9 & No & 174 & 0 & 0 & 6 & 0 & 0 & 0 & 0 & 0 & 0 \\
\hline \multirow[t]{2}{*}{ Walnut } & 2006-2013 & $\begin{array}{l}\text { Tehama, Butte, } \\
\text { Yuba, Yolo, Sutter, } \\
\text { Solano, San Joaquin, } \\
\text { Kings, Tulare }\end{array}$ & 24 & Yes & 2,533 & 0 & 0 & 362 & 0 & 5 & 0 & 0 & 0 & 2 \\
\hline & & & & $\begin{array}{l}\text { Total } \\
\text { number }\end{array}$ & 14,659 & 334 & 17 & 911 & 61 & 788 & 415 & 205 & 19 & 8 \\
\hline
\end{tabular}

* Sites $x$ years sampled.

+ Yes $=$ samples collected at intervals throughout the crop season. $\mathrm{No}=$ one or a few samples collected. 
a high level of regulation of this group of spider mites due to their specialized feeding habits. However, when spider mites are scarce their populations decline. Type III and IV phytoseiids are able to survive when mite prey are scarce because of their generalized feeding habits.

During the 1970s and 1980s, Galendromus occidentalis (formerly called Typhlodromus occidentalis or Metaseiulus occidentalis), commonly known as the western predatory mite, was demonstrated to be a significant biological control agent of tetranychid spider mite pests, especially in almond (Hoy et al. 1979) and grape (Kinn and Doutt 1972). Based on these and other studies (McMurtry and Flaherty 1977; McMurtry et al. 1971; Rice and Jones 1978), the UC Integrated Pest Management (IPM) pest management guidelines listed G. occidentalis as a key beneficial predator for tetranychid spider mites (Tetranychus and Eotetranychus species) in almonds, apples, apricots, cherries, grapes, nectarines, peaches, pears and walnuts.
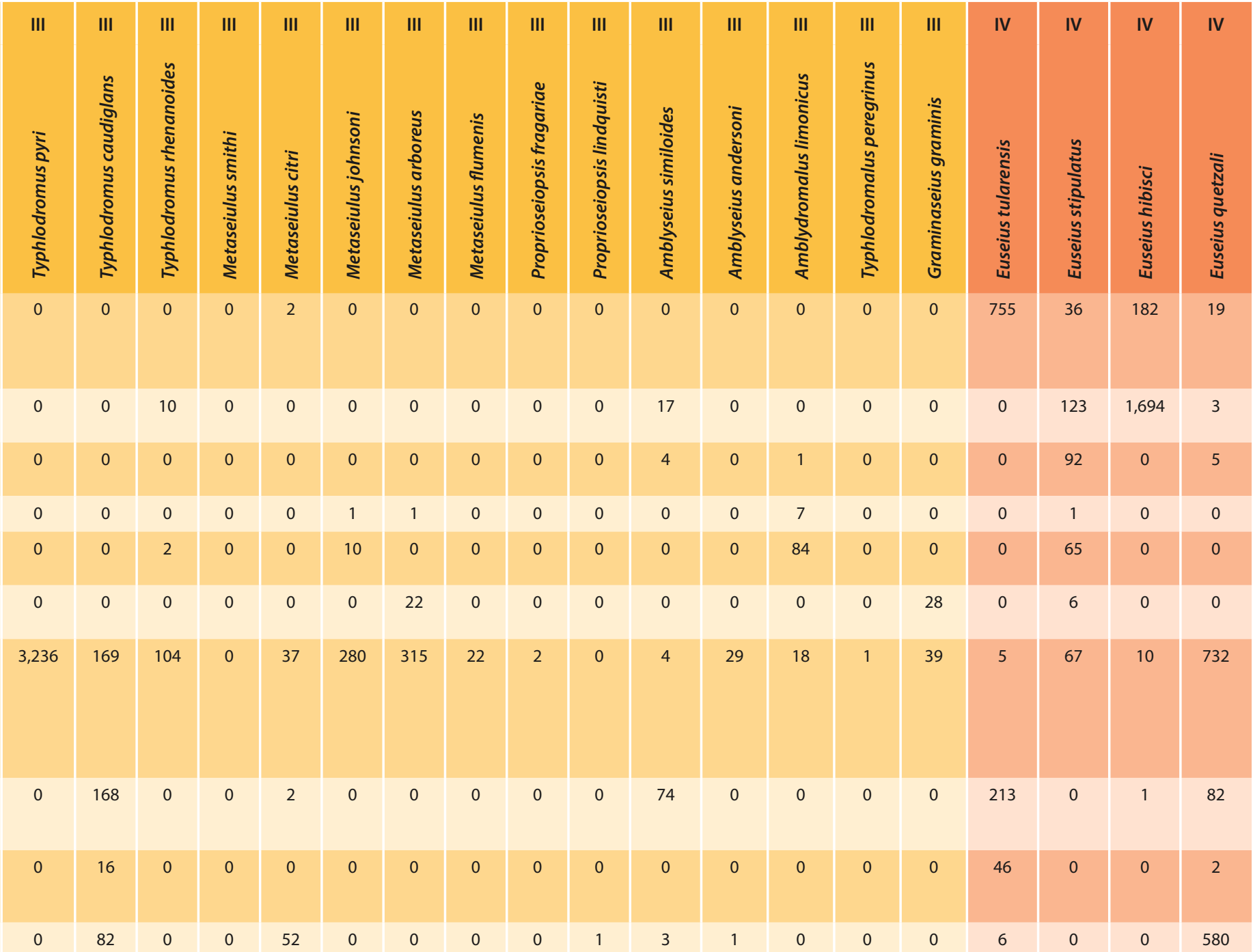

\begin{tabular}{|c|c|c|c|c|c|c|c|c|c|c|c|c|c|c|c|c|c|c|}
\hline 0 & 0 & 0 & 0 & 12 & 0 & 0 & 0 & 0 & 0 & 104 & 0 & 0 & 0 & 0 & 14 & 27 & 0 & 11 \\
\hline 0 & 223 & 0 & 1 & 90 & 0 & 0 & 0 & 0 & 0 & 919 & 0 & 0 & 0 & 0 & 78 & 596 & 10 & 247 \\
\hline
\end{tabular}


Pest control advisers (PCAs) learned to use spider mite/predatory mite ratios as thresholds for treatment in many of these crops to minimize pesticide use. Because phytoseiid species are difficult to distinguish with a hand lens, there was often a presumption by PCAs that any phytoseiid seen in these crops was $G$. occidentalis. Yet, not all phytoseiids are equally reliable in maintaining pests below an economic threshold.

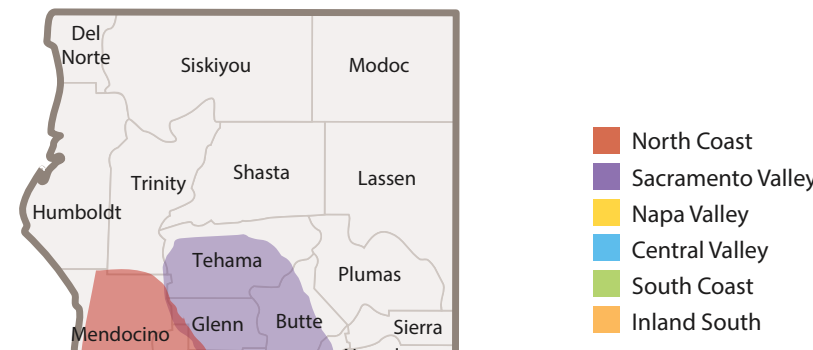

Slide mounted mite specimens for identification: (A) Phytoseiulus persimilis and (B) Euseius stipulatus.
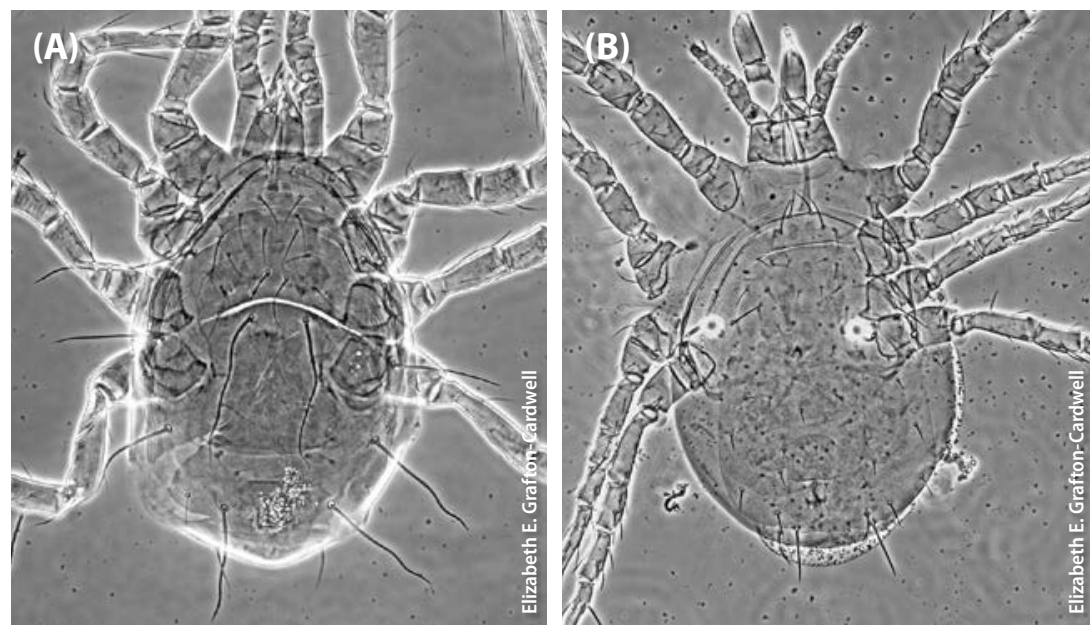

A survey of several crops by a high school student in the Ag Futures Internship Program at UC Kearney Agricultural Center in 1992 surprisingly revealed that the western predatory mite was not the dominant species.

That discovery led to the acquisition of funding from the UC Exotic/Invasive Pests and Diseases Research Program for us to survey a number of major crops - from 2005 to 2008 to determine predatory mite species frequency and diversity. We obtained additional collections of data on mites over the years from studies funded by commodity organizations.

\section{4,659 predatory mites, 12 crops, 25 counties}

From 2000 to 2018, UC Cooperative Extension (UCCE) advisors and specialists, UC faculty, UC technicians and a Cal Poly, San Luis Obispo, graduate student collected and identified 14,659 predatory mites from 12 crops - almonds, avocados, blackberries, cherimoyas, citrus, grapes, pears, peaches/nectarines, plums/ prunes, raspberries, strawberries and walnuts - in 25 counties of California encompassing six geographical regions (table 1, fig. 1). Mites were collected directly from leaves using an artist brush or a mite brushing machine, placed into $70 \%$ ethyl alcohol and slide mounted using Hoyers medium (Krantz and Walter 2009).

Identification of slide-mounted specimens of female mites was accomplished with the aid of a taxonomic key (Key to the Phytoseiid Predatory Mites of California Crops, developed by J. McMurtry and E.E. Grafton-Cardwell, in progress) and a phase contrast microscope. Some mite collections (in grapes, walnuts, strawberries, citrus, caneberries and cherimoyas) were made repeatedly in the same sites through one or more seasons. Other collections were made on one or a few dates during a season. Collectively, a total of 229 siteyears were sampled.

\section{Subtropical fruit: Dominated by Euseius species}

Three subtropical fruit crops were studied: avocados, cherimoyas and citrus (table 1, fig. 2). Surveys demonstrated that subtropical crops had low predatory mite species diversity (five to nine species total) and a strong tendency to support type IV Euseius species (93.3\% to $99.8 \%$ of specimens).

A total of 994 mites representing five species were identified from citrus in Fresno, Tulare, Kern, Santa Barbara, Riverside and San Bernardino counties from 2006 to 2018, and 99.8\% were in the genus Euseius (table 1, fig. 2). The Central Valley supported E. tularensis (96.8\%) and E. quetzali (3.1\%). In contrast, in the south coast area only E. stipulatus was found, and in inland Southern California a mixture of E. tularensis (46.5\%), E. stipulatus (3.3\%) and E. hibisci (50.1\%) was found. 
Previous studies described the distribution of $E$. tularensis and E. hibisci in California citrus (Congdon and McMurtry 1985, 1986; McMurtry et al. 1971, 1992). E. stipulatus was introduced to citrus in Southern California in 1972 (McMurtry 1977). The current study suggests that E. stipulatus has displaced E. hibisci in the southcoast area. The UC IPM guidelines for citrus (Dreidstadt 2012; Grafton-Cardwell et al. 2019) recommend conservation of Euseius species to aid in control of pest mites and thrips.

A total of 1,892 phytoseiids representing nine species were collected from avocado in San Luis Obispo and Orange counties from 2000 to 2007 , and $96.2 \%$ of these mites were in the genus Euseius (table 1, fig. 2). E. hibisci was the dominant species (95.8\% of Euseius species) found on inland Southern California avocados, and E. stipulatus was the dominant species $(96.0 \%$ of Euseius species) found on south coast avocados. Again, the abundance of E. stipulatus in the south coast area is a significant change from the 1960s through the 1980s, when E. hibisci dominated that region (Congdon and McMurtry 1985; McMurtry and Johnson 1965, 1966). The UC IPM guidelines for avocado (Dreidstadt 2008; Faber et al. 2018) list Neoseiulus californicus, E. hibisci, Galendromus annectans, G. helveolus and Amblydromalus limonicus as important predators of pest mites.

A total of 104 phytoseiids representing five species were identified from cherimoya in the south coast area (Santa Barbara and Ventura counties) during 2006 and 2007 , and $93.3 \%$ of these mites were in the genus Euseius (table 1, fig. 2), including E. stipulatus (88.5\%) and E. quetzali (4.5\%). This is the first report of phytoseiids in cherimoyas (Murrietta 2015) and provides further evidence that $E$. stipulatus has established in south coast California subtropical crops.

\section{Berries: Specialized spider mite predators}

In contrast to the subtropical crops that hosted primarily type IV phytoseiid species, blackberries, raspberries and strawberries supported a high percentage of type I and II specialized spider mite predators: Phytoseiulus, Typhlodromina, Galendromus and Neoseiulus species (fig. 3). Collections in our study were likely affected by augmentative releases of these phytoseiids by growers for tetranychid pest mites.

A total of 106 mites representing eight species were collected from blackberries in San Luis Obispo County, and $90 \%$ were identified as type I Typhlodromina ehari (8\%) and type II species: N. californicus (46.2\%) and Galendromus species (35.8\%) (table 1, fig. 3). A previous study in blackberry by McMurtry and Show (2012) revealed lower diversity (only two species) compared to our untreated commercial site or the wild blackberries in their study, indicating pesticide effects on diversity.

A total of 239 mites represented by seven species were collected from raspberries in San Luis Obispo and Ventura counties, including type I $P$. persimilis

(20.9\%), type II N. californicus (10.9\%), type III

Amblydromalus limonicus (35.1\%) and type IV Euseius

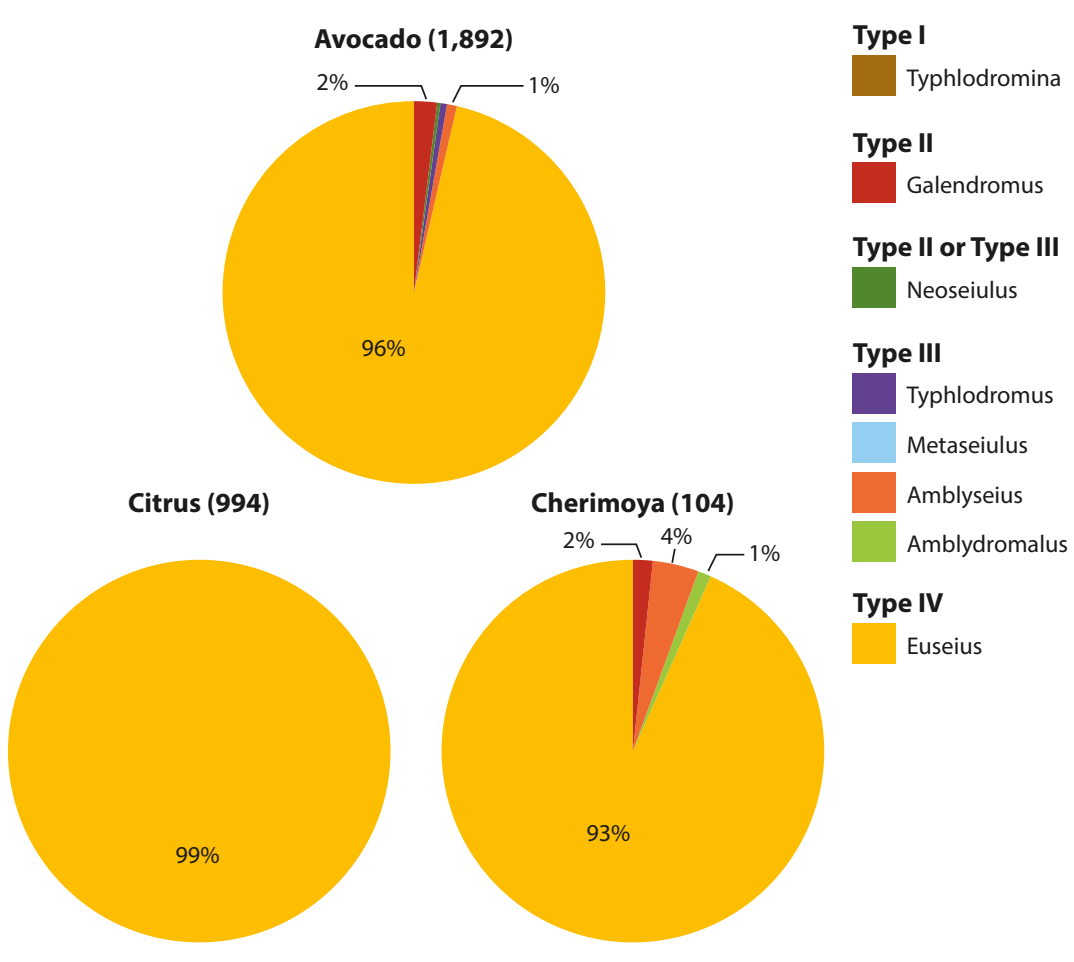

FIG. 2. Percentage of each phytoseiid predatory mite genus found in citrus, avocado and cherimoya (number of specimens).

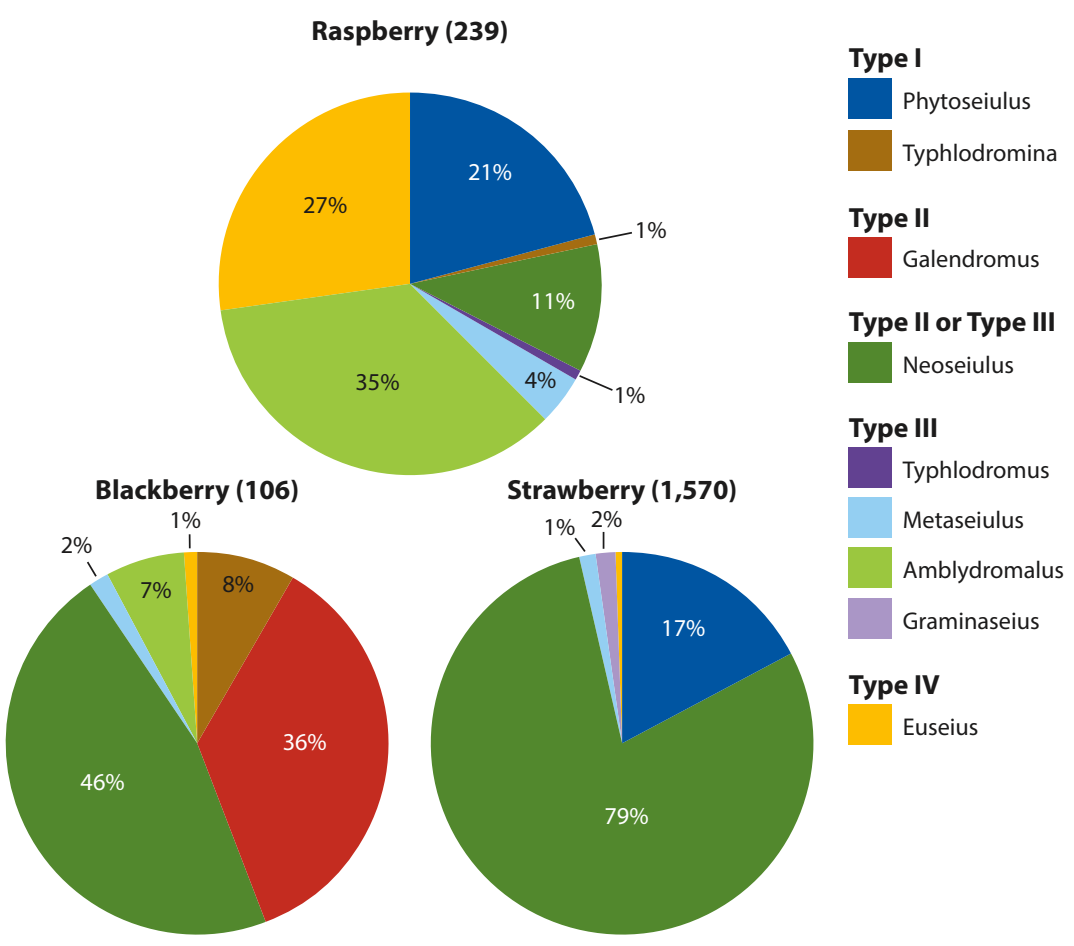

FIG. 3. Percentage of each phytoseiid predatory mite genus found in blackberry, raspberry and strawberry (number of specimens). 

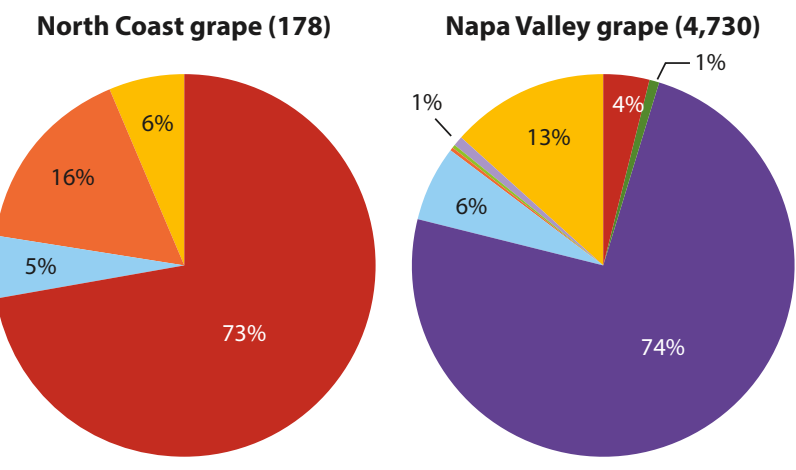

\section{Central Valley grape (107)}
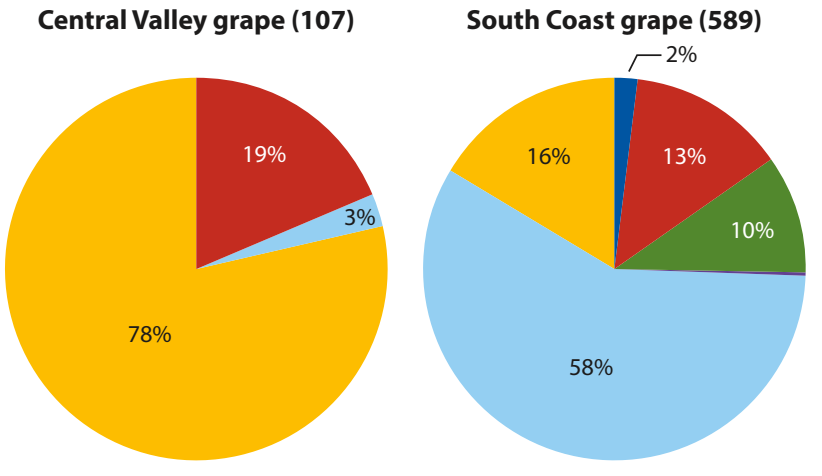

stipulatus (27.2\%) (table 1, fig. 3). Significant numbers of E. stipulatus found in south coast raspberries again demonstrate establishment of this species in this region. Raspberries had a greater number of type III and IV phytoseiids than blackberries; however, the blackberry crop was represented by only one surveyed site. The UC IPM guidelines for caneberries discuss releases of $P$. persimilis for control of mites (Bolda et al. 2018b).

A total of 1,570 mites representing nine species were collected from strawberries in Santa Barbara, Ventura and Santa Cruz counties, including type I $P$. persimilis (17.3\%) and type II and III Neoseiulus species (79.2\%) (table 1, fig. 3). Because of early research demonstrating the efficacy of releases (Oatman et al. 1977), growers regularly use phytoseiid releases for tetranychid mite control in strawberries. The UC IPM guidelines for strawberry state that $P$. persimilis and $N$. californicus have established in south coast strawberries, and these were the two dominant species found in Santa Barbara and Ventura county surveys (Bolda et al. 2018a; Strand 2008). The Santa Cruz County survey revealed five species of Neoseiulus: N. californicus (35.6\%), N. aurescens (41.1\%), N. cucumeris (20.8\%), N. brevispinus (1.9\%) and $N$. barkeri (0.5\%), suggesting greater species diversity of Neoseiulus in this county. Our study revealed E. stipulatus in south coast strawberries. four regions (number of specimens).

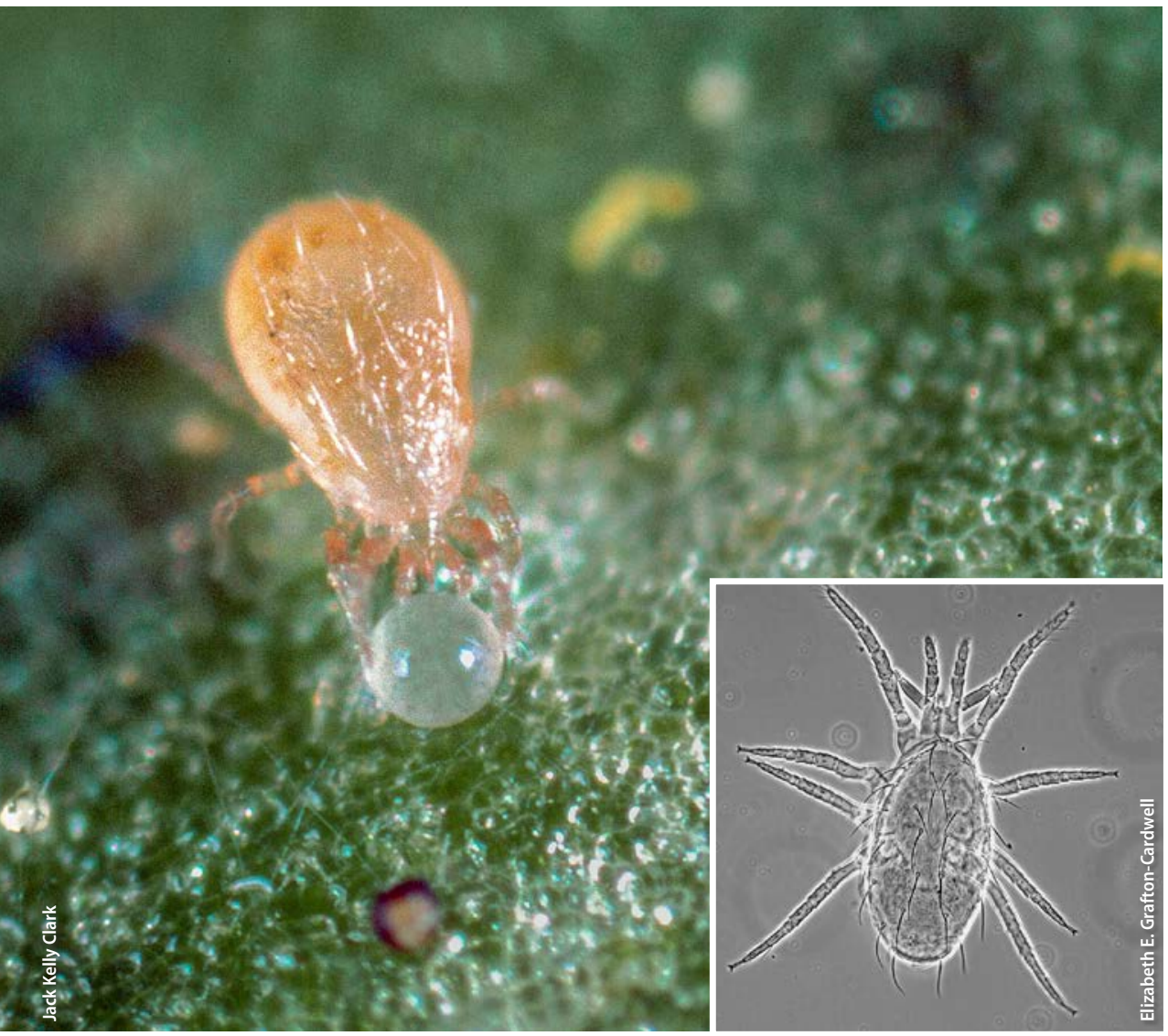

Adult western predatory mite Galendromus (Metaseiulus) occidentalis attacking a twospotted spider mite egg. Inset: Galendromus occidentalis specimen as seen under a compound microscope.

\section{Grapes: Greatest phytoseiid diversity}

Grapes (table 1, fig. 4) had the greatest diversity of phytoseiids (24 of 28 total species collected from all crops). However, the greater diversity found may be due to the higher number of ecological niches sampled. A total of 5,604 mites were collected from 10 counties, and species composition varied greatly by region. The dominant genera in north coast vineyards were type II Galendromus (72.5\%) and type III Amblyseius (16.3\%) species; in the Napa Valley, type III Typhlodromus (74.2\%) and type IV Euseius (13.2\%) species dominated; in the Central Valley, type II Galendromus (18.7\%) and type IV Euseius (78.5\%) were most common; and in south coast vineyards, type II Galendromus (13.2\%), type III Metaseiulus (58.1\%) and type IV Euseius (16.1\%) species prevailed. The UC IPM guidelines for grape, updated based on the surveys described in this study, list G. occidentalis, T. pyri, E. quetzali, E. tularensis, E. stipulatus, Neoseiulus fallacis, N. californicus and M. mcgregori [M. flumenis] as beneficial species, with species dominance varying from region to region (Bettiga 2013; Haviland et al. 2019).

The differences in species composition could be explained by a number of factors, including variations in climate, prey species, neighboring crops and pesticide treatments (Hanna et al. 1997; Stavrinides and Mills 2009). Previous research (Flaherty and Huffaker 1970) in the Central Valley revealed a similarly high 
level of species diversity in grape and listed E. hibisci as the sole Euseius species collected. However, at that time, E. tularensis, E. stipulatus and E. quetzali had not yet been described (Congdon and McMurtry 1985). Our collections revealed all four species of Euseius, with E. stipulatus present in the south coast and Napa Valley regions, E. hibisci in the south coast, E. tularensis in the Central Valley and south coast and E. quetzali statewide.

\section{Stone fruit and pears: Additional species found}

A previous survey of peaches, nectarines and plums (Rice and Jones 1978) indicated that Typhlodromus caudiglans, Metaseiulus citri, Galendromus occidentalis and Euseius hibisci were the key phytoseiids in the Central Valley. Our study provided evidence of these but also additional species such as Amblyseius similoides, and the previously undescribed E. tularensis and $E$. quetzali.

A total of 576 mites representing eight species were collected from peaches and nectarines in Butte, Fresno, Kings, Tulare and Kern counties. The dominant species found were type II G. occidentalis (6.1\%), type III T. caudiglans (29.2\%) and A. similoides (12.8\%) and type IV Euseius species (51.4\%) (table 1, fig. 5). The UC IPM guidelines for peaches and nectarines list G. occidentalis as the key phytoseiid for control of key pest spider mites (Day et al. 2017a, 2017b; Strand 1999), yet this species accounted for only $6.1 \%$ of the specimens collected.

A total of 67 mites representing four species were collected from plum and prune orchards in Butte and Kern counties (table 1, fig. 5). The major species found were type II G. occidentalis (4.5\%), type III T. caudiglans (23.9\%) and type IV E. tularensis (71.6\%). The UC IPM guidelines for plums and prunes suggest T. caudiglans and Galendromus species as effective control agents for key pest mites (Adaskaveg et al. 2017; Bentley et al. 2017).

A total of 800 mites representing nine species were collected from pear orchards in Lake, Mendocino, Sacramento and Yolo counties (table 1, fig. 5). The predominant species were type II G. occidentalis (8.9\%), type III T. caudiglans (10.3\%) and M. citri (6.5\%) and type IV E. quetzali (72.5\%). This is the first published survey of phytoseiids in pear. The UC IPM guidelines for pear list G. occidentalis for the control of key pest mites (Elkins et al. 2017; Ohlendorf 1999), yet this species represented $<9 \%$ of mites collected.

\section{Nuts: Few phytoseiids in almonds}

A total of 174 mites representing six species were collected from almond orchards in Kern and Butte counties (table 1, fig. 6). The predominant species were type III Amblyseius similoides (59.8\%) and type IV Euseius species (29.9\%). The UC IPM guidelines for almond list

Galendromus occidentalis as the key predacious mite for tetranychid pest mite control (Flint 2002; Haviland et al. 2017). However, G. occidentalis represented a minor percentage (3.4\%) of species collected. It should be noted that we searched almond sites for several years

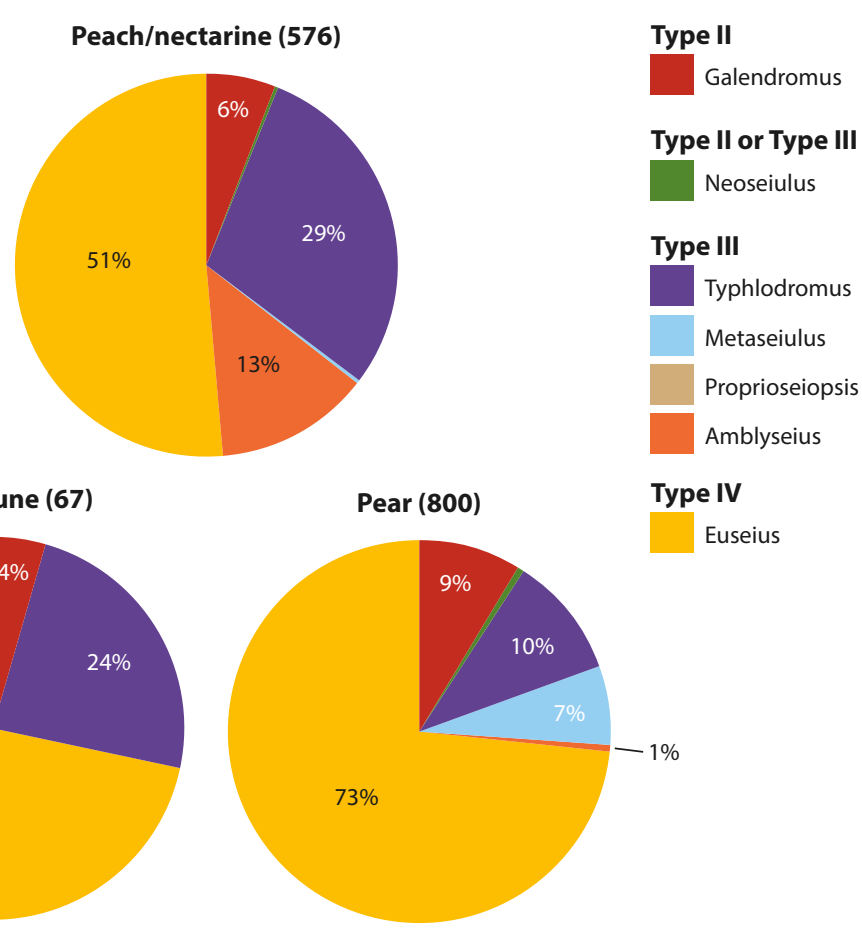

FIG. 5. Percentage of each phytoseiid predatory mite genus found in stone fruit and pear (number of specimens).

Sacramento Valley and Central Valley almond (174)

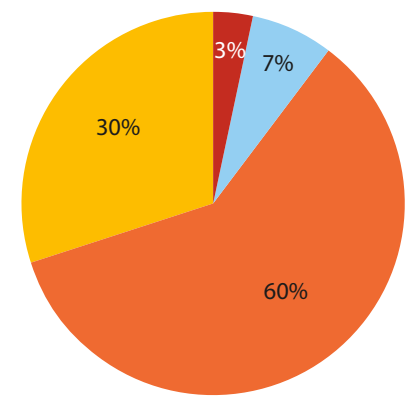

Central Valley walnut $(1,556)$

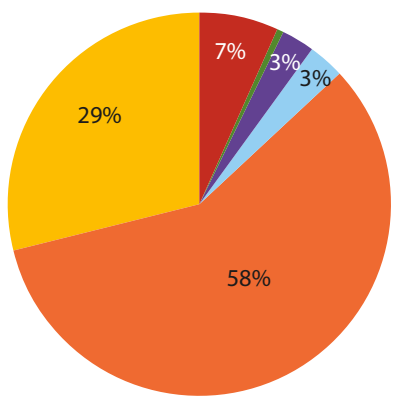

Sacramento Valley walnut (977)

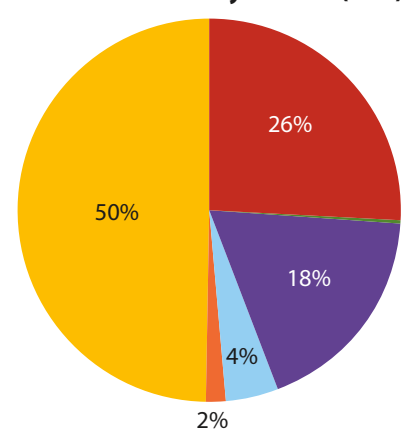

FIG. 6. Percentage of each phytoseiid predatory mite genus found in nut crops, with walnut sampled from two regions (number of specimens). 


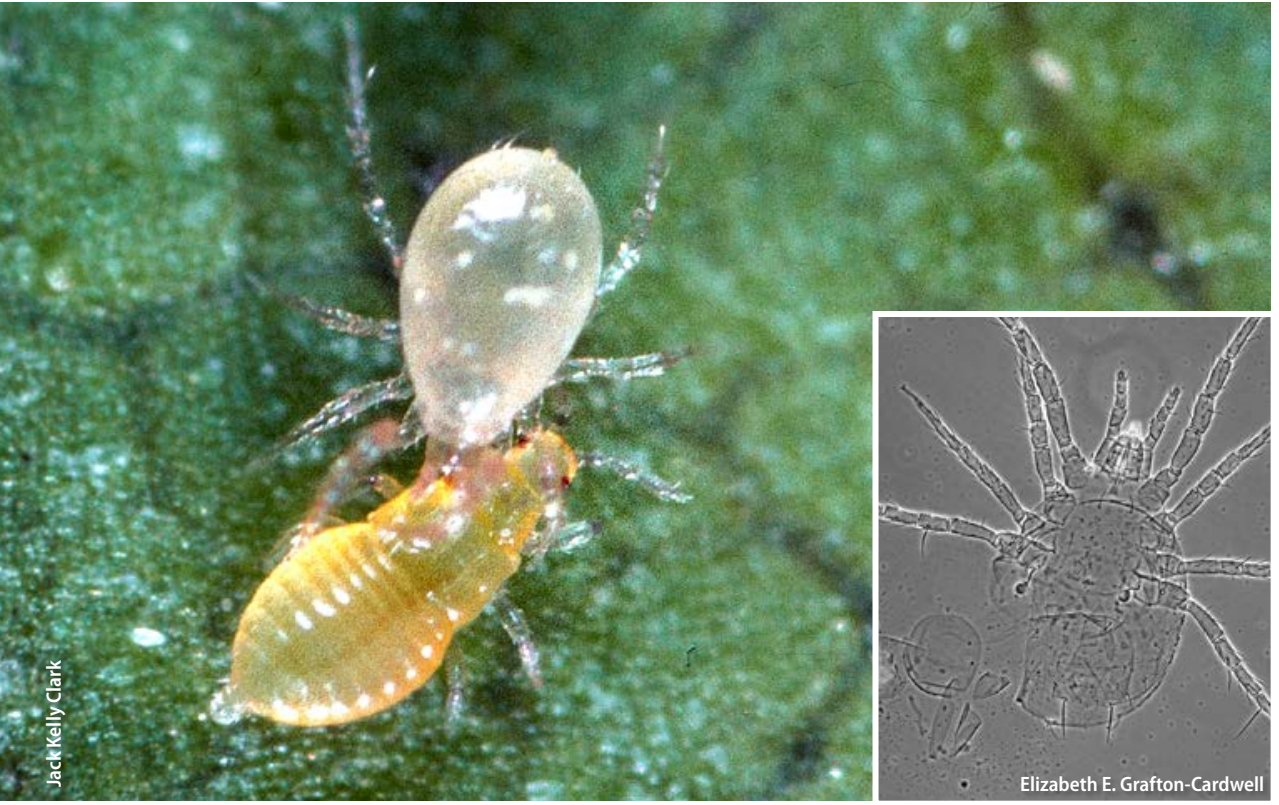

Euseius tularensis predatory mite, top, feeding on a citrus thrips nymph, bottom. Inset: Euseius tularensis specimen as seen under a compound microscope. to obtain these collections and routinely found very few phytoseiids. The low populations of phytoseiids compared to decades ago may be explained by changes in chemical control programs that favor a second-level predator, the sixspotted thrips, Scolothrips sexmaculatus, which feeds on both tetranychids and phytoseiids.

A total of 2,533 mites representing 11 species were collected from walnut orchards in Tehama, Butte, Yuba, Yolo, Sutter, Solano, San Joaquin, Kings and Tulare counties (table 1, fig. 6). When we examined the results by geographical region, the predominant genera in the Central Valley were very similar to almonds, with type III Amblyseius species (58.0\%) and type IV Euseius species (28.7\%) dominating. In contrast, walnuts grown in the Sacramento Valley had a much higher percentage of type II G. occidentalis (26.1\%) and type III Typhlodromus species (18.1\%), in addition to type IV Euseius species (49.5\%) and very low numbers of type III Amblyseius (1.7\%) species. The UC IPM guidelines for walnut indicate that G. occidentalis is the key predator of walnut pest mites (Grant et al. 2017; Strand 2003). However, it was found in much lower abundance in the Central Valley region than the Sacramento Valley.

\section{Diversity levels, changes}

The surveys in this study were undertaken to determine the level of diversity of phytoseiids in perennial crops in six regions of California and look for changes in species composition compared to earlier studies (Congdon and McMurtry 1985, 1986; Hoy et al. 1979; Kinn and Doutt 1972; McMurtry and Flaherty 1977; McMurtry and Johnson 1965; McMurtry et al. 1971; McMurtry et al. 1979; McMurtry and Show 2012; Oatman 1971; Rice and Jones 1978; Rice et al. 1976). Similar to these other studies, our surveys found low phytoseiid diversity in subtropical crops, extremely high levels of diversity in grapes and moderate levels in tree fruits, nuts and berries. Berries hosted the greatest proportion of type I Phytoseiulus persimilis and type II Neoseiulus californicus, likely due to augmentative releases and/or establishment from prior releases of the commercially available predators.

The presence of Euseius stipulatus in citrus, avocados, cherimoyas, grapes, strawberries, blackberries, raspberries, almonds and walnuts is interesting because this species was introduced to citrus in Southern California in 1972 (McMurtry 1977) for the control of citrus red mite. It is now found as far north as the Sacramento Valley in walnut orchards and Napa Valley, and it appears to have displaced E. hibisci to a great extent in south coast subtropical crops.

The western predatory mite, Galendromus occidentalis, has long been recognized as an important biological control agent in California crops, as evidenced by its mention in many of the UC IPM guidelines. Our survey demonstrated that G. occidentalis was often a minor component of the phytoseiid complex, playing a major role only in grape, Sacramento Valley walnut and south coast blackberries. Previous authors noted that G. occidentalis populations decline when tetranychid prey are lacking and this species is sensitive to insecticides (Hoy et al. 1979; Rice and Jones 1978).

The predatory mite complexes differed significantly between geographical regions for walnuts and grapes, and studies need to be undertaken to determine the underlying basis for these differences. In addition, studies are needed to evaluate the roles and effectiveness of the abundant type III and type IV phytoseiid species, such as Typhlodromus, Amblyseius and Euseius species, in the stone, pear and nut crops. Are these species regulators of key pests such as mites and thrips? Or are they feeding on pollen or nonpest mites such as tydeiids, eriophyids and tarsonemids and insignificant for agricultural pest control? Most of our surveys were carried out without monitoring plant-feeding prey, but clearly there are host plant and prey influences. Additional work is needed to elucidate the impact of pest phenology, climate, crop variety, alternative prey and crop management activities on the abundance of phytoseiid species and their ability to regulate pest populations.

A significant impediment to evaluating the role of predatory mites in field situations is that they are difficult to identify to species using a hand lens because of their rapid movement, small size and similar appearance. Yet, there are large differences in their ability to regulate pest populations. As mentioned, a taxonomic key is being prepared for publication, but it requires slide-mounted specimens and a phase-contrast microscope. Consequently, phytoseiid identification may be limited for professionals who have no access to specialized equipment. Future work may take advantage of rapid advancements in and declining costs of field-usable molecular tools to quickly identify mites. If future 
research establishes the efficacy of the various phytoseiid species and a rapid identification method becomes available, then PCAs can make real-time decisions and avoid unnecessary pesticide applications. CA

E.E. Grafton-Cardwell and M. Hoddle are UC Cooperative Extension (UCCE) Specialists, J. McMurtry (deceased) was retired Professor of Entomology, and P. Gu and Y. Ouyang are Staff Research Associates, Department of Entomology, UC Riverside; W. Bentley is retired UCCE IPM Advisor, Kearney Agricultural Research and Extension Center; M. Bianchi is retired UCCE Farm Advisor, San Luis Obispo and Santa Barbara counties; F.E. Cave is retired Staff Research Associate and N. Mills is Professor, Department of Environmental Science, Policy and Management, UC Berkeley; R. Elkins is UCCE Farm Advisor, Lake and Mendocino counties; L. Godfrey (deceased) was UCCE Specialist,
Department of Entomology, UC Davis; D. Haviland is UCCE Entomology Advisor and S. Rill is UCCE Staff Research Associate, Kern County; D. Headrick is Professor, Department of Horticulture and Crop Science, Cal Poly San Luis Obispo; M. Murrietta is UCCE Farm Advisor Assistant, San Luis Obispo County; C. Pickel is retired UCCE IPM Advisor, Sutter and Yuba counties; M.C. Stavrinides is Assistant Professor, Department of Agricultural Sciences, Biotechnology and Food Sciences, Cyprus University of Technology; and L.G. Varela is UCCE IPM Advisor, North Coast.

This project was partially funded by the UC Exotic/Invasive Pests and Diseases Research Program, the California Walnut Board, the Citrus Research Board, the California Avocado Commission, the Almond Board of California, the California Pear Advisory Board, the Pear Pest Management Research Fund, the American Vineyard Foundation, Viticulture Consortium West, Raisin Marketing Board, a UC ANR Core Issue Grant and the California State University Agricultural Research Institute.

\section{References}

Adaskaveg JE, Buchner RP, Gubler WD, et al. 2017. Prune: UC IPM Pest Management Guidelines. UC ANR Pub 3464. Oakland, CA: UCANR.

Bentley WJ, Day KR, Duncan R, et al. 2017. Plum: UCIPM Pest Management Guidelines. UC ANR Pub 3462. Oakland, CA UC ANR

Bettiga L. 2013. Grape Pest Management (3rd ed.). UC ANR Pub 3343. Oakland CA: UC ANR.

Bolda MP, Browne GT, Dara SK, et al. 2018a. Strawberry: UC IPM Pest Management Guidelines. UC ANR Pub 3468. Oakland, CA: UC ANR

Bolda MP, Joseph S, Daugovish O, et al. 2018b. Caneberries: UC IPM Pest Management Guidelines. UC ANR Pub 3437. Oakland, CA: UCANR.

Congdon B, McMurtry JA. 1985. Biosystematics of Euseius on California citrus and avocado with the description of a new species (Acari: Phytoseiidae). Int J Acarol 11:23-30.

Congdon BD, McMurtry JA. 1986. The distribution and taxonomic relationships of Euseius quetzali McMurtry in California (Acari: Phytoseiidae). Int J Acarol 12:7-11.

Day KR, Tollerup K, Duncan R, et al. 2017a. Nectarine: UC IPM Pest Management Guidelines. UC ANR Pub 3451. Oakland, CA: UC ANR.

Day KR, Tollerup K, Duncan R, et al. 2017b. Peach: UC IPM Pest Management Guidelines. UC ANR Pub 3454. Oakland, CA: UC ANR.

Dreidstadt S. 2008. Integrated Pest Management for Avocados. Statewide Integrated Pest Management Program, UC ANR Pub 3503. Oakland CA: UC ANR.
Dreidstadt S. 2012. Integrated Pest Management for Citrus (3rd ed.). Statewide Integrated Pest Management Program, UC ANR Pub 3303. Oakland CA: UC ANR

Elkins RB, Varela LG, Roncoroni JA, et al. 2017. Pear: UC IPM Pest Management Guidelines. UC ANR Pub 3455. Oakland, CA: UC ANR

Faber BA, Willen CA, Eskalen A, et al. 2018. Avocado: UC IPM Pest Management Guidelines. UC ANR Pub 3436. Oakland, CA UC ANR.

Flint ML. 2002. Integrated Pest Management for Almonds (2nd ed.). Statewide Integrated Pest Management Program, UC ANR Pub 3308. Oakland CA: UC ANR Flaherty DL, Huffaker CB. 1970 Biological control of pacific mites and Willamette mites in San Joaquin Valley vineyards. I. Role of Metaseiulus occidentalis. II. Influence of dispersion patterns of Metaseiulus occidentalis. Hilgardia 40:267-330.

Grafton-Cardwell EE، Faber BA, Haviland DR, et al. 2019. Citrus: UC IPM Pest Management Guidelines. UC ANR Pub 3441. Oakland, CA: UC ANR

Grant JA, Symmes EJ, Baldwin RA, et al. 2017. Walnut: UCIPM Pest Management Guidelines. UC ANR Pub 3471. Oakland, CA UC ANR.

Hanna R, Wilson LT, Zalom FG, Flaherty DL. 1997. Effects of predation and competition on the population dynamics of Tetranychus pacificus on grapevines. Appl Ecol 34:878-88.

Haviland DR, Bettiga LJ, Varela LG, et al. 2019. Grape: UCIPM Pest Management Guidelines. UC ANR Pub 3448. Oakland, CA UC ANR.
Haviland DR, Symmes EJ, Adaskaveg JE, et al. 2017. Almond: UC IPM Pest Management Guidelines. UC ANR Pub 3431. Oakland, CA: UCANR.

Hoy MA, Roush RT, Smith KB, Barclay LW. 1979. Spider mites and predators in San Joaquin Valley almond orchards. Calif Agr 33:11-3

Kinn DN, Doutt RL. 1972. Natural control of spider mites on wine grape varieties in Northern California. Environ Entomol 1:513-8. Krantz GW, Walter DE (eds.). 2009. A Manual of Acarology (3rd ed.). Lubbock, TX: Texas Tech Univ Pr. 807 p.

McMurtry JA. 1977. Some predacious mites (Phytoseiidae) on citrus in the Mediterranean region. Entomophaga 22:19-30.

McMurtry JA, Croft BA. 1997. Life-styles of phytoseiid mites and their roles in biological control. Annu Rev Entomo 42:291-321

McMurtry JA, de Moraes GJ, Sourassou NF. 2013. Revision of the lifestyles of phytoseiid mites (Acari: Phytoseiidae) and implications for biological control strategies. Syst Appl Acarol 18:297-320.

McMurtry JA, Flaherty DL. 1977. An ecological study of phytoseiid and tetranychid mites on walnut in Tulare County, California. Environ Entomol 6:287-92.

McMurtry JA, Johnson HG. 1965. Some factors influencing the abundance of the predaceous mite Amblyseius hibisci in Southern California (Acarina: Phytoseiidae). Ann Entomol Soc Amer 58:49-56.

McMurtry JA, Johnson HG

1966. An ecological study of the spider mite Oligonychus punicae (Hirst) and its natural enemies. Hilgardia 37:363-402.
McMurtry JA, Morse JG, Johnson HG. 1992. Studies of the impact of Euseius species (Acari: Phytoseiidae) on citrus mites using predator exclusion and predator release experiments. Exp Appl Acarol 15:233-48.

McMurtry JA, Oatman ER Fleschner CA. 1971. Phytoseiid mites on some tree and row crops and adjacent wild plant in Southern California. J Econ Entomol 64:405-8.

McMurtry JA, Shaw JG, Johnson HG. 1979. Citrus red mite populations in relation to virus disease and predaceous mites in Southern California. Environ Entomol 8:160-4.

McMurtry JA, Show ED. 2012. Phytoseiidae on blackberry in Central California. Syst Appl Acarol 17:384-7.

Murrietta ME. 2015. Survey of Phytoseiids (Acari: Phytoseiidae) on the Central Coast of California. Master's thesis, Department of Horticulture and Crop Science, Cal Poly State Univ, San Luis Obispo, California. https:// digitalcommons.calpoly.edu/ theses/1388

Oatman ER. 1971. Mite species on strawberry in Southern California. J Econ Entomo 64:1313-4

Oatman ER, McMurtry JA, Gilstrap FE, Voth V. 1977. Effect of releases of Amblyseius californicus, Phytoseiulus persimilis and Typhlodromus occidentalis on the twospotted spider mite on strawberry in Southern California. J Econ Entomol 70:45-7.

Ohlendorf B. 1999. Integrated Pest Management for Apples and Pears (2nd ed.). Statewide Integrated Pest Management Program, UC ANR Pub 3340 Oakland, CA: UC ANR

Rice RE, Jones RA. 1978. Mites in almonds and stone fruits. Calif Agr 43:20-1.
Rice RE, Jones RA, Hoffman ML. 1976. Seasonal fluctuations in phytophagous and predacious mite populations on stonefruits in California. Environ Entomol 5:557-64.

Schuster RO, Pritchard AE. 1963. Phytoseiid mites of California. Hilgardia 34(7):191-8.

Stavrinides MC, Mills NJ. 2009. Demographic effects of pesticides on biological control of Pacific spider mite (Tetranychus pacificus) by the western predatory mites (Galendromus occidentalis). Biol Control 48:267-73.

Strand LL. 1999. Integrated Pest Management for Stone Fruits. Statewide Integrated Pest Management Program, UC ANR Pub 3389. Oakland CA: UC ANR. Publication 3389

Strand LL. 2003. Integrated Pest Management for Walnuts (3rd ed.). Statewide Integrated Pest Management Program, UC ANR Pub 3270. Oakland CA: UC ANR. Strand LL. 2008. Integrated Pest Management for Strawberries (2nd ed.). Statewide Integrated Pest Management Program, UC ANR Pub 3351. Oakland CA: UC ANR. 